\title{
THE STUDY OF CHLORIDE ION TRANSPORT BEHAVIOR OF MORTAR UNDER DIFFERENT STORING ENVIRONMENT TEMPERATURES
}

\author{
Shih-Han Weng \\ Institute of Materials Engineering, National Taiwan Ocean University, Keelung, Taiwan, R.O.C. \\ Chung-Chia Yang \\ Institute of Materials Engineering, National Taiwan Ocean University, Keelung, Taiwan, R.O.C., \\ ccyang@mail.ntou.edu.tw \\ Shih-Wei Cho \\ Department of Architecture, China University of Science and Technology, Taipei, Taiwan, R.O.C. \\ Kuo-Cheng Yang \\ Department of Mechanical and Mechatronic Engineering, National Taiwan Ocean University, Keelung, Taiwan, R.O.C
}

Follow this and additional works at: https://jmstt.ntou.edu.tw/journal

Part of the Civil and Environmental Engineering Commons

\author{
Recommended Citation \\ Weng, Shih-Han; Yang, Chung-Chia; Cho, Shih-Wei; and Yang, Kuo-Cheng (2012) "THE STUDY OF CHLORIDE ION \\ TRANSPORT BEHAVIOR OF MORTAR UNDER DIFFERENT STORING ENVIRONMENT TEMPERATURES," Journal of \\ Marine Science and Technology. Vol. 20: Iss. 3, Article 7. \\ DOI: $10.51400 / 2709-6998.1806$ \\ Available at: https://jmstt.ntou.edu.tw/journal/vol20/iss3/7 \\ This Research Article is brought to you for free and open access by Journal of Marine Science and Technology. It has been \\ accepted for inclusion in Journal of Marine Science and Technology by an authorized editor of Journal of Marine Science and \\ Technology.
}




\title{
THE STUDY OF CHLORIDE ION TRANSPORT BEHAVIOR OF MORTAR UNDER DIFFERENT STORING ENVIRONMENT TEMPERATURES
}

\author{
Shih-Han Weng ${ }^{1}$, Chung-Chia Yang ${ }^{1}$, Shih-Wei Cho ${ }^{2}$, and Kuo-Cheng Yang ${ }^{3}$
}

Key words: chloride, aggregates volume fractions, temperature.

\begin{abstract}
This study presents the chloride ion transport behavior of mortar from accelerated chloride migration test (ACMT). The water/cement ratio of mortars is 0.45 , and the five volume fractions of fine aggregates $(0 \%, 15 \%, 30 \%, 50 \%$ and $60 \%)$ were evaluated. After stored under different environment temperatures $\left(25^{\circ} \mathrm{C}, 40^{\circ} \mathrm{C}, 60^{\circ} \mathrm{Cand} 80^{\circ} \mathrm{C}\right)$, the chloride ion passing through specimens was carried out with ACMT. From the Nernest-Planck equation and modified Fick's second law, test data could be calculate the chloride migration coefficient of non-steady-state and steady-state. For mortar structure, dilution and tortuosity effects are positive effect to resist the penetration of Chloride ion. On the contrary, ITZ and percolation effects are negative effect to resist the penetration of Chloride ion. Thus the migration coefficients of mortar at $60 \%$ volume fractions of fine aggregates is higher than other mixes because of ITZ and percolation effects.
\end{abstract}

\section{INTRODUCTION}

Temperature is one of the causes to affect the pore structure of mortar, thus it is need to notice the effects of specimens under different temperatures on the transport properties.

Diamond and Mindess [3] indicated the mechanical and transport properties of cement-based materials was influenced by pore structure. The hydrated matrix of surrounding the fine aggregate has different water/cement ratio gradient developed at the interfacial layer, and the layer around the aggregate is called the ITZ (interfacial transition zone) [3], ITZ has a higher concentration of calcium hydroxide crystals and much

Paper submitted 03/25/11; revised 10/21/11; accepted 01/18/12. Author for correspondence: Chung-Chia Yang (e-mail: ccyang@mail.ntou.edu.tw)

${ }^{1}$ Institute of Materials Engineering, National Taiwan Ocean University, Keelung, Taiwan, R.O.C.

${ }^{2}$ Department of Architecture, China University of Science and Technology, Taipei, Taiwan, R.O.C.

${ }^{3}$ Department of Mechanical and Mechatronic Engineering, National Taiwan Ocean University, Keelung, Taiwan, R.O.C.
Table 1. Mix design, volume fraction of aggregate.

\begin{tabular}{|c|c|c|c|c|c|}
\hline \multicolumn{4}{|c|}{ Unit: $\mathrm{Kg} / \mathrm{m}^{3}$} & \multicolumn{2}{c|}{ Fine Aggregate } \\
\hline Mix & Water & Cement & $\mathrm{SP}^{*}$ & Sand & $V_{f}$ \\
\hline M0 & 574.6 & 1276.9 & 0 & 0 & 0 \\
\hline M15 & 486.6 & 1081.3 & 0 & 390.3 & 0.15 \\
\hline M30 & 398.8 & 886.2 & 0 & 779.6 & 0.3 \\
\hline M50 & 278.2 & 618.2 & 6.18 & 1299.8 & 0.5 \\
\hline M60 & 217.7 & 483.8 & 9.68 & 1559.8 & 0.6 \\
\hline
\end{tabular}

* The dosage of superplasticizer (SP) was adjusted to obtain the required slump and slump flow.

more porosity than matrix paste $[6,8,10,13]$.

Because the specimens were stored at $40^{\circ} \mathrm{C}, 60^{\circ} \mathrm{C}$ and $80^{\circ} \mathrm{C}$ for 56 days after 28 days cured in water, the size of pores and micro-cracking may increase, and caused connect and increase the transport property of mortar. However, the effect upon the transport properties of mortar under different temperatures is rarely determined. Hence, to investigate the transport properties of mortar which were storing at $40^{\circ} \mathrm{C}, 60^{\circ} \mathrm{C}$ and $80^{\circ} \mathrm{C}$ for 56 days is the purpose of this study. By the accelerated chloride migration test (ACMT), the transport properties (steady-state migration coefficient and non-steady state migration coefficient) of unheated specimen (Air, $25^{\circ} \mathrm{C}$ ) and heated specimen of mortar were studied and compared.

\section{EXPERIMENTAL PROGRAM}

\section{Materials and Specimen Preparation}

Mortar is a cement-based composite in which fine aggregates are embedded in a matrix of cementitious paste [12]. In this study, the water/cement ratio was 0.45 , specimens were made of ASTM Type I Portland cement, water, and superplasticizer. In order to understand the influence of aggregate on the chloride migration coefficient of mortar, different volume fractions of fine aggregate $\left(V_{f}\right.$, the volume of aggregate/ mortar) which is from $0 \%$ to $60 \%$ were selected in the mix proportions (shown in Table 1).

Before specimens of mortar were stored at $40^{\circ} \mathrm{C}, 60^{\circ} \mathrm{C}$ and $80^{\circ} \mathrm{C}$ for 56 days in the oven, each cylindrical specimen $(\varnothing 100 \times 200 \mathrm{~mm})$ was cast, and cured in water $(23 \pm 2$ degree $)$ 


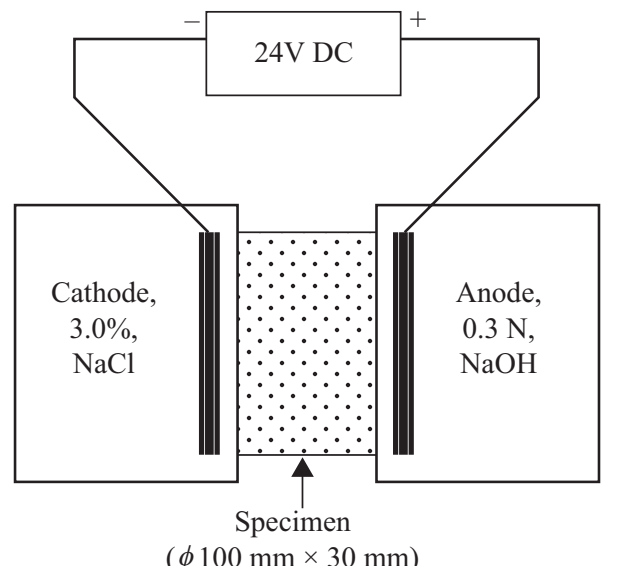

Fig. 1. Schematic diagram of ACMT [11].

for 28 days. It was taken from the middle part of cylindrical specimen (30 $\mathrm{mm}$ in thickness), and its' the lateral surface were coated with epoxy, then were put in the vacuum desiccators until the pressure is smaller than $1 \mathrm{~mm} \mathrm{Hg}(133 \mathrm{MPa})$ for $3 \mathrm{hrs}$. After turning off the pump of vacuum, the specimens still were placed in water for immersing $18 \mathrm{hrs}$. Then these specimens were ready to setup of ACMT. For ACMT, all the specimens were prepared following the specification of ASTM C1202-97.

\section{Experimental Procedure}

In this study, the accelerated chloride migration test (ACMT) was developed to measure and obtain the concentration of cumulative chloride ions passing through the specimen under 24 voltages (shown in Fig. 1) [7].

The specimen was placed between two acrylic cells, then two \#20 mesh brass screens electrodes (10 cm diameter) were set on two sides of the specimen. In ACMT, electrical fields could be manipulated to pass through specimen; one of the cells was filled with $0.30 \mathrm{~N} \mathrm{NaOH}$ solution $4500 \mathrm{ml}$, the other cell with $3.0 \% \mathrm{NaCl}$ solution $4500 \mathrm{ml}$. As Fig. 1 shown, two cells were connected to a $24 \mathrm{~V}$ DC power source in which the $\mathrm{NaOH}$ electrode is the anode and the $\mathrm{NaCl}$ electrode is the cathode [7]. In anode cell, the chloride concentration was measured and obtained periodically by using an ion chromatograph.

\section{RESULTS AND DISCUSSION}

\section{Chloride Migration in ACMT}

From the curve of chloride concentration-time with ACMT, it is a method to study the specimen permeability of materials. From the solution in the anodic cell of ACMT, the chloride concentration was measured and determined. There were three stages (see in Fig. 2) which are non-steady-state, transition period, and steady-state [8].

Yang et al. [12] indicated that "in the non-steady-state, the chloride ions are in the process of migrating through saturated

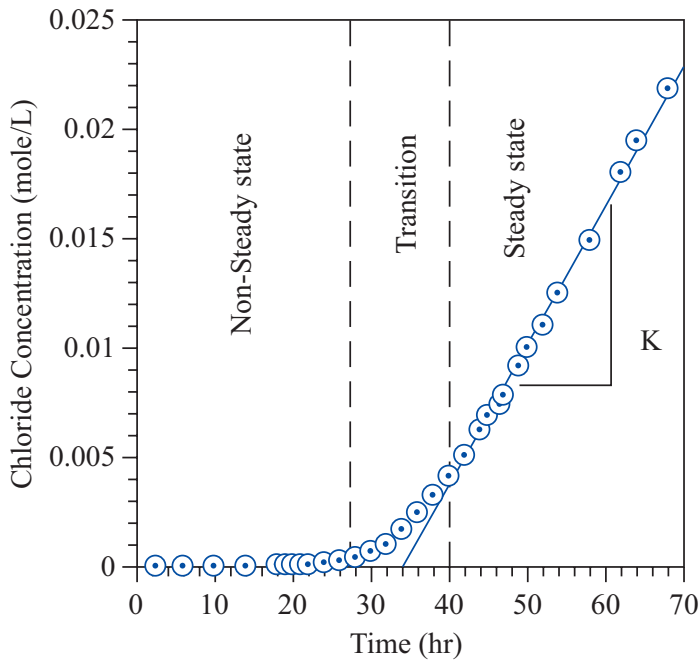

Fig. 2. The typical result of chloride concentration as a function of time.

pores in concrete and have not yet reached the anodic cell. In this stage, the chloride ions cannot be determined in the anodic cell. In the transition period, the first chloride ions penetrate through the specimen, and there is an uneven distribution of the chloride content in the specimen. The chloride concentration in the anodic cell is low, and the result shown nonlinear during the transition period. In the steady-state, the flux of chloride ions passing through the concrete specimen becomes constant."

From describes and statement given above, it could be obtained the chloride migration coefficient of non-steady-state and the steady-state by ACMT.

\section{Non-Steady-State Chloride Migration Coefficient and Transition Period}

The typical result of chloride concentration in the transition period was showen in Fig. 3. For the transition period, because the chloride concentration is intermittently monitored and the time-span is hard to determine, a regression line is carried out portion of the chloride-time curve, it would be determined the chloride ion penetration through specimen from time-span as:

$$
C=a t^{b}, \quad \text { for transition period }
$$

Where $C$ is the chloride concentration in anodic cell, $t$ is the elapsed time, $a$ and $b$ are experimental constants. In Fig. 3, the breakthrough time $t$ is correspond to $C / C_{0}=0.05 \%\left(C / C_{0}\right.$, chloride concentration in anodic cell/ chloride concentration in source cell) $[4,12]$, and it was calculated from Eq. (1). From the modified Fick's second law, the non-steady-state migration coefficient can be calculated as [4]:

$$
M_{n}=\frac{1}{\beta}\left[\frac{x-\alpha \sqrt{x}}{t}\right]
$$


Table 2. The non-steady-state migration coefficient $\left(M_{n} *\right.$ $10^{-12} \mathrm{~m}^{2} / \mathrm{sec}$ ) under $25^{\circ} \mathrm{C}, 40^{\circ} \mathrm{C}, 60^{\circ} \mathrm{C}$ and $80^{\circ} \mathrm{C}$.

\begin{tabular}{|c|c|c|c|c|c|c|c|c|}
\hline \multirow{2}{*}{$V_{f}$} & \multicolumn{2}{|c|}{$M_{n \_} 25$} & \multicolumn{2}{c|}{$M_{n \_} 40$} & \multicolumn{2}{c|}{$M_{n \_} 60$} & \multicolumn{2}{c|}{$M_{n \_} 80$} \\
\cline { 2 - 9 } & $t$ & $M_{n}$ & \multicolumn{1}{c}{$t$} & $M_{n}$ & $t$ & $M_{n}$ & $t$ & $M_{n}$ \\
\hline 0 & 14.85 & 16.13 & 9.62 & 25.7 & 5.39 & 39.3 & 4.05 & 61 \\
\hline 15 & 17.88 & 15.6 & 10.01 & 24.2 & 5.23 & 38 & 4.29 & 54.5 \\
\hline 30 & 18.05 & 13 & 10.26 & 22.5 & 7.93 & 32 & 5.43 & 50 \\
\hline 50 & 14.03 & 19 & 10.40 & 26.3 & 5.00 & 45 & 5.43 & 50 \\
\hline 60 & 9.83 & 21 & 7.93 & 32.3 & 4.00 & 60 & 2.94 & 93.7 \\
\hline
\end{tabular}

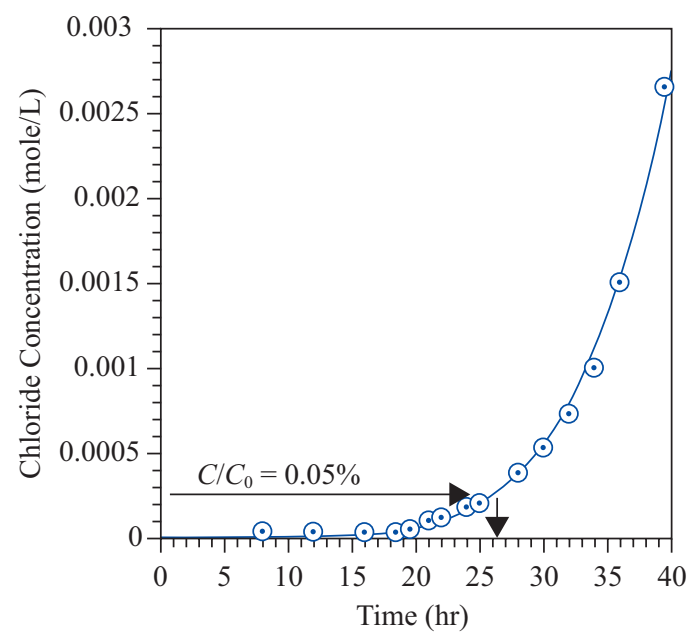

Fig. 3. The typical result of chloride concentration as a function of time in the transition period.

$$
\text { Where } \beta=|z| F E / R T, \alpha=2 \sqrt{1 / \beta} e^{-1}\left(1-\left(2 C / C_{0}\right)\right)
$$

$M_{n}$ is non-steady-state migration coefficient in $\mathrm{m}^{2} \mathrm{sec}^{-1}, z$ is the electrical charge of chloride, $F$ is the Faraday constant $(F=$ $\left.96,500 \mathrm{~J} / \mathrm{V} \times \mathrm{mole}^{-1}\right), E$ is the strength of the electric field between the anode and cathode $(v), R$ is the universal gas constant $\left(R=8.314 \mathrm{~J} \times \mathrm{mole}^{-1} \mathrm{~K}^{-1}\right), T$ is absolute temperature $(\mathrm{K}), C$ is chloride concentration in the anodic cell $\left(\right.$ mole $\left.\times \mathrm{L}^{-1}\right)$, $C_{0}$ is chloride concentration in the source cell $\left(\right.$ mole $\left.\times \mathrm{L}^{-1}\right)$ and $\operatorname{erf}^{-1}$ is the inverse of error function. By using the breakthrough time $t$, the non-steady-state migration coefficients $\left(M_{n}\right)$ for all specimens are calculated from Eq. (2), and listed in Table 2.

The M40_25 of mix means that w/c equal to $0.45,0 \%$ aggregate of volume fraction under $25^{\circ} \mathrm{C}$. The M41_25 of mix means that $\mathrm{w} / \mathrm{c}$ equal to $0.45,15 \%$ aggregate of volume fraction under $25^{\circ} \mathrm{C}$. It also could be understood that, the M45_60 of mix means that $\mathrm{w} / \mathrm{c}$ equal to $0.45,50 \%$ aggregate of volume fraction under $60^{\circ} \mathrm{C}$.

\section{Steady-State Chloride Migration Coefficient}

In steady-state, the steady-state chloride migration rate $(K)$ was calculated to determine the skill of chloride ion penetration, linear regression is carried out from experimental data for the steady-state curve as:
Table 3. The steady-state migration coefficient $\left(M_{s} * 10^{-12} \mathrm{~m}^{2} /\right.$ sec) under $25^{\circ} \mathrm{C}, 40^{\circ} \mathrm{C}, 60^{\circ} \mathrm{C}$ and $80^{\circ} \mathrm{C}$.

\begin{tabular}{|c|c|c|c|c|c|c|c|c|}
\hline \multirow{2}{*}{$V_{f}$} & \multicolumn{2}{|c|}{$M_{s-} 25$} & \multicolumn{2}{|c|}{$M_{s-} 40$} & \multicolumn{2}{|c|}{$M_{s_{-}} 60$} & \multicolumn{2}{|c|}{$M_{s-} 80$} \\
\hline & $J$ & $M_{s}$ & $J$ & $M_{s}$ & $J$ & $M_{s}$ & $J$ & $M_{s}$ \\
\hline 0 & 1.81 & 11.6 & 2.58 & 16.8 & 6.02 & 38 & 7.8 & 48 \\
\hline 15 & 1.62 & 11.2 & 2.41 & 15.6 & 5.51 & 33.3 & 6.28 & 39.7 \\
\hline 30 & 1.15 & 7.3 & 2.16 & 13.6 & 3.3 & 30 & 4.9 & 31.9 \\
\hline 50 & 1.52 & 10.3 & 4.01 & 27 & 6.22 & 40 & 7.6 & 45 \\
\hline 60 & 3.41 & 20.4 & 4.42 & 32 & 8.93 & 56 & 8.3 & 57 \\
\hline
\end{tabular}

$$
C=K t+c, \quad \text { for steady state }
$$

As shown in Fig. 2, using the Nernst-Planck's equation, the steady-state migration coefficient, $M_{\mathrm{s}}$ is calculated as [1]:

$$
M_{s}=\frac{R T}{\left(|z| C_{0} F E\right)} \frac{V K}{A}
$$

Where $V$ is the volume of solution in anodic cell $\left(\mathrm{m}^{3}\right)$, and $A$ is the specimen surface exposed to chloride ions $\left(\mathrm{m}^{2}\right)$. By using the chloride migration rate $(K)$ and Eq. (4), the steadystate migration coefficient $\left(M_{s}\right)$ for all specimens is calculated, and listed in Table 3.

\section{Effect of Aggregate Volume Fraction on the Chloride Migration Coefficient}

\section{1) Dilution and Tortuosity Effects}

The migration coefficient of fine aggregate is much lower than cement pastes, if the bond between aggregate and cement paste is perfect, the migration coefficient of mortar will be less than the cement paste. Because the migration coefficient of fine aggregate is less than the cement paste, the dilution effect has happened.

In the ACMT, because the aggregate blocks the flow paths, the permeable area in a cross-section of mortar is reduced [9], in addition, for the dilution effect, it depends on the volume fraction of aggregate, and the aggregate is relatively impermeable and a linear parallel chloride ion flow exists [8].

For the dilution effect, the chloride migration coefficient of mortar $M_{c l}$ can be expressed as [5]:

$$
M_{c l}=M_{0}\left(1-V_{f}\right)
$$

Where, $M_{0}$ is the migration coefficient of cement paste, and $V_{f}$ is the volume fraction of fine aggregate. For the tortuosity effect, it has happened due to the impermeability of the fine aggregates, which means chloride ions migration could be forced flowing around the aggregate particles, so increasing the length of flow paths and reducing the flow rate. From describing and statement given above, combining the tortuosity effect with the dilution effect, in this study, the chloride migration coefficient of mortar can be expressed by the Bruggeman equation [2]: 


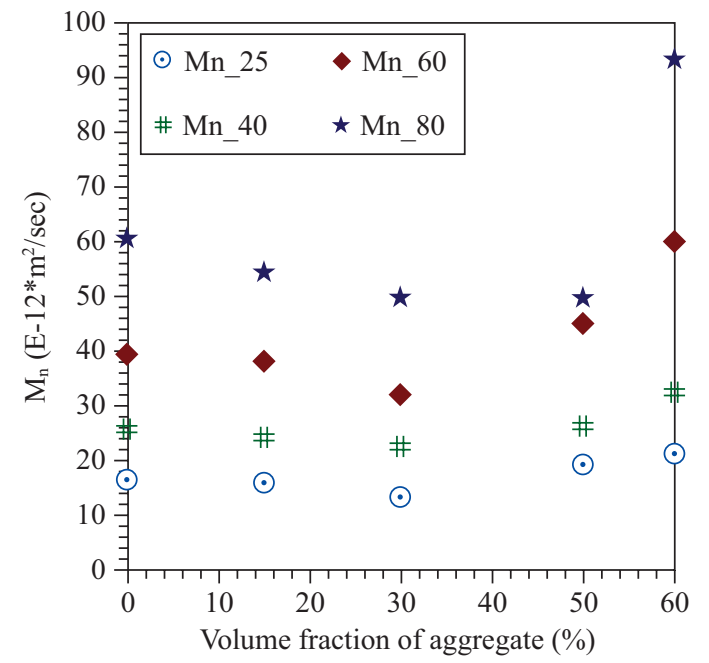

Fig. 4. The non-steady-state migration coefficient of mortar with $0 \%$ $60 \%$ aggregate volume fraction.

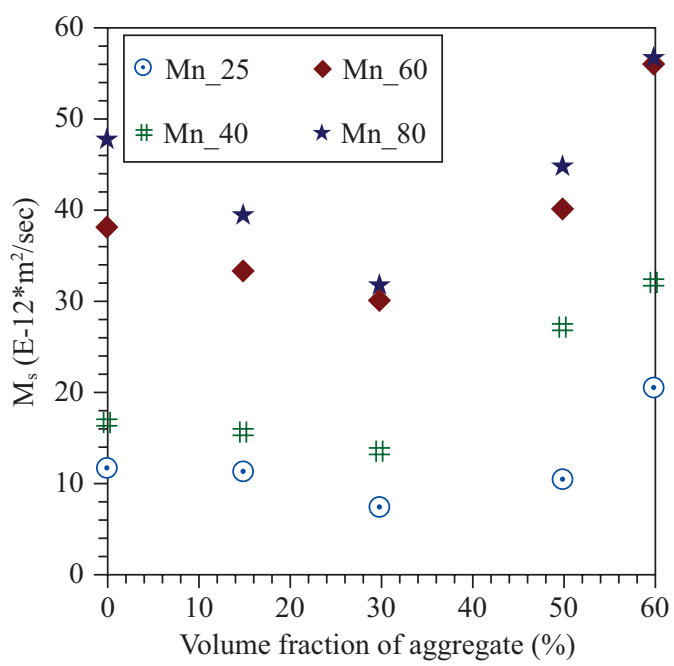

Fig. 5. The steady-state migration coefficient of mortar with $0 \% \sim 60 \%$ aggregate volume fraction.

$$
M_{c l}=M_{0}\left(1-V_{f}\right)^{3 / 2}
$$

In Figs. 4 and 5 , the specimens of under $25^{\circ} \mathrm{C}, 40^{\circ} \mathrm{C}, 60^{\circ} \mathrm{C}$ and $80^{\circ} \mathrm{C}$, they show that the increase of volume fraction aggregate is following with decrease of migration coefficient of mortar while volume fraction of fine aggregate is less than approximate 40\%. In Figs. 6 and 7, the theoretical chloride migration coefficient of mortar with $0.45 \mathrm{w} / \mathrm{c}$ ratio are showed and are compared with the calculated results from Eq. (5) and (6). The theoretical chloride migration coefficient $M_{s} / M_{0}$ is defined as the ratio of the mortar chloride migration coefficient and the cement paste chloride migration coefficient.

Comparing the experimental data with the results in Fig. 6, the chloride migration coefficient of $25^{\circ} \mathrm{C}$ is influenced by the dilution effect and tortuosity effect when the volume fraction

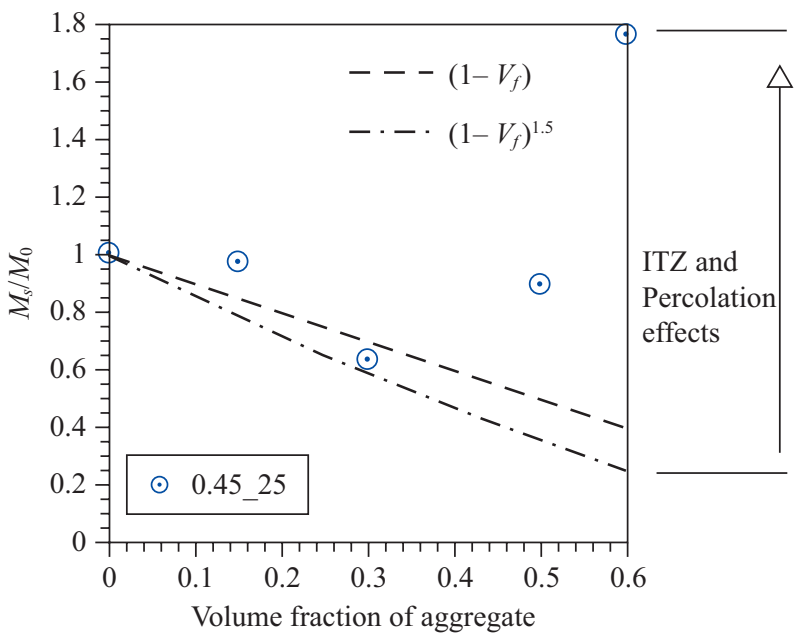

Fig. 6. The specimen of under $25^{\circ} \mathrm{C}$, the chloride migration coefficients $\left(M_{s} / M_{0}\right)$ and volume fraction of fine aggregate for mortar.

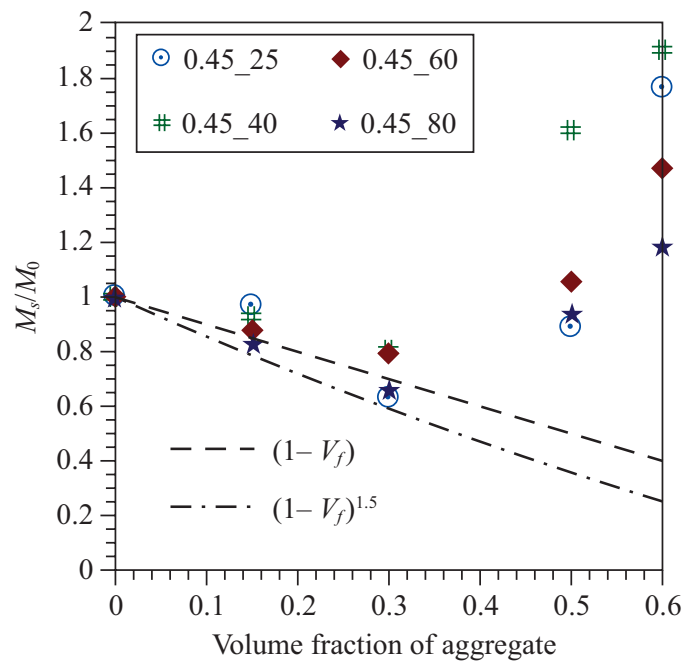

Fig. 7. the chloride migration coefficients' $\left(M_{s} / M_{0}\right)$ and volume fraction of fine aggregate for mortar.

of fine aggregate less than 0.3. At $V_{f}=0.3$, when only the dilution effect is considered, the theoretical chloride migration coefficient reduces from 1.0 to 0.7 , as combining the tortuosity effect with the dilution effect, the theoretical chloride migration coefficient reduces from 1.0 to 0.65 . However, when the volume fraction of fine aggregate is higher than 0.3 , the length of flow paths are increased. As experimental data shown from Fig. 6, the chloride migration coefficient is not only influenced by dilution and tortuosity effects.

Under $40^{\circ} \mathrm{C}, 60^{\circ} \mathrm{C}$ and $80^{\circ} \mathrm{C}$, Fig. 7 showes the increase of volume fraction aggregate is following with decrease of migration coefficient of mortar while volume fraction aggregate is less than approximate $30 \%$.

\section{2) ITZ and Percolation Effects}

In this study, mortar is considered as a three-phase com- 
posite material (cement paste, fine aggregate, and ITZ).

The ITZ develops between fine aggregate and matrix, it was made chloride ions accelerating ingress and movement, and also increasing the chloride migration coefficient of mortar. The percolation effect occurs as the flow path that connects and percolates the ITZs and increasing the flow rate [12].

In Fig. 6 under $25^{\circ} \mathrm{C}$, as the volume fraction of fine aggregate is higher than $0.4 \sim 0.5$, the percolation of ITZs may happen. Therefore, the M46_25 mixes are not only controlled by the dilution and tortuosity effects but also the ITZ and percolation effects. Relativity, under $40^{\circ} \mathrm{C}, 60^{\circ} \mathrm{C}$ and $80^{\circ} \mathrm{C}$, the Fig. 7 also indicated that the volume fraction of fine aggregate is higher than 0.3 , some ITZs have been connected. Thus, the M45_40, M46_40, M45_60, M46_60, M45_80 and M46_80 mixes are not only controlled by the dilution and tortuosity effects but also the ITZ and percolation effects.

In Fig. 6, under $25^{\circ} \mathrm{C}$, the chloride migration coefficient was about $0.5 \sim 0.7$ as the volume fraction of fine aggregate is $0.3 \sim 0.4$, that means the influence of ITZ is not significant due to the fact that percolation has not happen at such low sand volume fraction. In Fig. 7, the chloride migration coefficients increase sharply as the volume fraction of fine aggregate is higher than 0.3 , particularly, at $60 \%$ fine aggregate of volume fraction. At the $30 \%$ volume fraction of fine aggregate, when the specimens were stored under higher $40^{\circ} \mathrm{C}$, some percolation effect may occurred because of the overlap of more porous ITZ regions and appearing more micrococracking.

The main factor that influences the durability of mortar is the migration coefficient of chloride ion. In general, constituent phases and their geometric arrangement controls concrete migration coefficient. The dilution and tortuosity effect decreases the permeability of mortar. However, by comparison, the ITZ and percolation effect increases the permeability of mortar.

\section{CONCLUSIONS}

The transport properties of mortar were influenced by the temperature. In this study, the effect of temperatures at $40^{\circ} \mathrm{C}$, $60^{\circ} \mathrm{C}$ and $80^{\circ} \mathrm{C}$ on the chloride migration coefficients of mortar were studied. Based on the results obtained from the present experimental investigation, the following conclusions can be drawn:

1. The increase of volume fraction aggregate is following with decrease of migration coefficient of mortar while volume fraction aggregate is less than approximate $40 \%$.

2. The specimen of under $25^{\circ} \mathrm{C}$, the result indicated that as the volume fraction of fine aggregate is higher than $0.4 \sim 0.5$, the percolation of ITZs may happen. The M46_25 mixes are not only controlled by the dilution and tortuosity effects but also the ITZ and percolation effects.

3. The specimen of under $40^{\circ} \mathrm{C}, 60^{\circ} \mathrm{C}$ and $80^{\circ} \mathrm{C}$, the volume fraction of fine aggregate is higher than 0.3 , some ITZs have been connected. Thus, the specimens which are stored at higher than $40^{\circ} \mathrm{C}$ are not only controlled by the dilution and tortuosity effects but also the ITZ and percolation effects.

4. The specimen of under $25^{\circ} \mathrm{C}$, the chloride migration coefficient was about $0.5 \sim 0.7$ as the volume fraction of fine aggregate is $0.3 \sim 0.4$, that means the influence of ITZ is not significant due to the fact that percolation has not happen at such low sand volume fraction.

5. The chloride migration coefficients increase sharply as the volume fraction of fine aggregate was over 0.3 , particularly, at $60 \%$ fine aggregate of volume fraction. At the $30 \%$ volume fraction of fine aggregate, when the specimens were stored under higher $40^{\circ} \mathrm{C}$, some percolation effect may occurred because of the overlap of more porous ITZ regions and appearing more micrococracking.

\section{REFERENCES}

1. Andrade, C., "Calculation of chloride diffusion coefficients in concrete from ionic migration measurements," Cement and Concrete Research, Vol. 23, No. 3, pp. 724-742 (1993).

2. Bruggeman, D. A. G., "Calculation different physical constant from heterogeneous substance I. Dielectric and conductivity mix-term of isotropic substance," Annals of Physics, Vol. 24, pp. 636-679 (1935).

3. Diamond, A. S. and Mindess, S., "The microstructure of the steel fibercement interface," Journal of Materials Science, Vol. 20, pp. 3610-3620 (1985).

4. Halamickova, P., Detwiler, R. J., Bentz, D. P., and Garboczi, E. J., "Water permeability and chloride ion diffusion in portland cement mortars: Relationship to sand content and critical pore diameter," Cement and Concrete Research, Vol. 25, No. 4, pp. 790-802 (1995).

5. Shah, S. P., "High performance concrete: past, present and future," in: Leung, C. K., Li, Z., and Ding, J. T. (Eds.), High Performance Concrete Workability, Strength and Durability, The Hong Kong University of Science and Technology, Hong Kong, pp. 3-29 (2000).

6. Simeonov, P. and Ahmad, S., "Effect of transition zone on the elastic behavior of cement-based composities," Cement and Concrete Research, Vol. 25, No. 1, pp. 165-176 (1995).

7. Tong, L. and GjØrv, O. E., "Chloride diffusivity based on migration testing," Cement and Concrete Research, Vol. 31, No. 7, pp. 973-982 (2001).

8. Yang, C. C., "The relationship between charge passed and the chloride concentrations in anode and cathode cells using the accelerated chloride migration test," Materials and Structures, Vol. 36, No. 10, pp. 678-684 (2003).

9. Yang, C. C. and Cho, S. W., "Influence of aggregate content on the migration coefficient of concrete materials using electrochemical method," Materials Chemistry and Physics, Vol. 80, No. 3, pp. $752-757$ (2003).

10. Yang, C. C. and Huang, R., "Double inclusion model for approximate elastic moduli of concrete material," Cement and Concrete Research, Vol. 26, No. 1, pp. 83-91 (1996).

11. Yang, C. C. and Huang, R., "A two phase model for predicting the compressive strength of concrete," Cement and Concrete Research, Vol. 26, No. 10, pp. 1567-1677 (1996).

12. Yang, C. C. and Liang, C. H., "The influence of medium-high temperature on the transport properties of concrete by using accelerated chloride migration test," Materials Chemistry and Physics, Vol. 114, Nos. 2-3, pp. 670-675 (2009).

13. Yang, C. C., Lin, Y. Y., and Huang, R., "Elastic modulus of concrete affected by elastic moduli of mortar and artificial aggregate," Journal of Marine Science and Technology, Vol. 4, No. 1, pp. 43-48 (1996). 